\title{
SIFAT FILLER KAYU KERUING TERHADAP VULKANISAT KARET
}

\author{
Herminiwati $^{1)}$, Nursamsi Sarengat ${ }^{1)}$, Purnomo Darmadji ${ }^{2)}$ dan Widya Meidrianto ${ }^{2)}$
}

\section{INTISARI}

Penelitian ini bertujuan untuk mengetahui sifat filler kayu keruing dalam aplikasinya pada vulkanisat karet sol sepatu. Untuk mengetahui kesesuaiannya sebagai filler barang karet, maka filler kayu keruing diteliti sifat-sifatnya dengan pembanding carbon black N330. Filler kayu keruing dibuat melalui proses karbonisasi pada suhu $450^{\circ} \mathrm{C}$ selama 1 jam dan proses aktivasi dengan $\mathrm{NaCl} 4 \%$ selama 24 jam diikuti dengan pirolisis pada suhu $500^{\circ} \mathrm{C}$ selama 1 jam. Filler digiling dan diayak dengan ayakan 400 mesh. Formula standar kompon dibuat berdasar ASTM D 3192 dalam berbagai variasi kadar filler kayu keruing dan carbon black N330 secara sendiri maupun kombinasi.

Hasil penelitian menunjukkan bahwa penggunaan filler kayu keruing sebesar 30 sampai dengan 70 phr dapat memenuhi 75\% persyaratan SNI.12-0172-1987 : Sepatu Kanvas Untuk Umum, sedangkan penggunaan carbon black N330 sebesar 30 sampai dengan 70 phr dapat memenuhi $87,5 \%$ persyaratan SNI 12-0172-1987. Kombinasinya dengan carbon black menunjukkan bahwa filler kayu keruing dapat mensubstitusi carbon black antara 25 sampai dengan $57 \mathrm{phr}$.

\section{ABSTRACT}

The purpose of this research was to investigate the properties of keruing wood filler in their application on vulcanized rubber of shoe soles. To know its suitability for rubber goods filler, the properties of keruing wood filler was investigated by comparing with carbon black N330. Keruing wood filler were made by carbonization process at temperature $450^{\circ} \mathrm{C}$ for one hour and activation process with $\mathrm{NaCl} 4 \%$ for twenty four hours, followed by pyrolisis at temperature $500^{\circ} \mathrm{C}$ for one hour. Filler were milled and sieved by 400 mesh siefter. The standard compound formula was prepared base on ASTM D 3192 with various filler level of keruing wood filler, carbon black N330 either separately formulated or combination. The research showed that using keruing wood filler in the amount of $30-70 \mathrm{phr}$ could meet $75 \%$ the requirements of SNI. 12-0172-1987 : Canvas shoes for general purpose, where as carbon black N330 in the amount of $30-70$ phr could meet $87,5 \%$ the requirements of SNI. 12 0172-1987. Combination of keruing wood filler and carbon black showed that keruing wood filler could subtitute 25-57 phr of carbon black.

\section{PENDAHULUAN}

Indonesia merupakan penghasil kayu nomor satu di dunia, dengan produksi ekspor 35 juta meter kubik per tahun. Dalam proses pengolahan kayu, hanya sekitar $60 \%$ kayu menjadi hasil, dengan limbah sisa kayu dan serbuk gergajian mencapai jumlah sekitar $30 \%$ (BPS, 1998). Dengan mengolah limbah sisa kayu dan serbuk gergajian ini menjadi material baru

1) Balai Besar Penelitian dan Pengembangan Industri Barang Kulit, Karet dan Plastik, Yogyakarta.

2) Fakultas Teknologi Pertanian UGM. 
yang bermanfaat dan bernilai ekonomis tinggi, misal memprosesnya menjadi filler barang karet, maka dapat meningkatkan nilai tambah hasil industri kayu, sekaligus mengurangi impor filler barang karet.

Dalam proses pengolahan dan pembuatan barang karet diperlukan filler yang tidak hanya berguna untuk memperbesar volume dan menekan harga, tetapi juga dapat berfungsi untuk memperbaiki dan meningkatkan sifat fisik dan mekanik barang karet yang dihasilkan sehingga sesuai dengan persyaratan yang ditetapkan. Eirick (1978) mengemukakan bahwa filler yang tergolong dapat meningkatkan sifat fisik dan mekanik barang karet serta banyak digunakan dalam pembuatan barang karet adalah carbon black yang merupakan filler aktif atau filler penguat. Penggunaan filler penguat ini akan meningkatkan sifat tegangan putus, ketahanan sobek, ketahanan kikis dan kekerasan. Carbon black N330 adalah filler yang banyak digunakan dalam pembuatan barang karet untuk meningkatkan ketahanan kikis seperti sol sepatu, telapak ban dll.

Menurut Morton (1987) sifat aktif dari suatu filler dipengaruhi oleh sifat fisika dan kimia yang meliputi : ukuran partikel, luas permukaan, struktur dan aktivitas permukaan. Untuk memperoleh efek penguatan yang optimum, maka partikel-partikel filler harus terdispersi dengan baik dan merata dalam kompon karet. Makin kecil ukuran partikel dan makin luas permukaan, maka makin besar kemungkinan terjadinya interaksi dengan molekul karet baik secara fisika maupun kimia. Demikian pula makin tinggi aktivitas permukaan, menunjukkan makin banyak gugus fungsional filler yang akan berikatan dengan molekul karet. Gugus fungsional seperti gugus fenolat, hidrogen reaktif, lakton, kuinon, hidroksil dan karboksil terdapat pada permukaan filler carbon black seperti tertera pada Gambar 1.

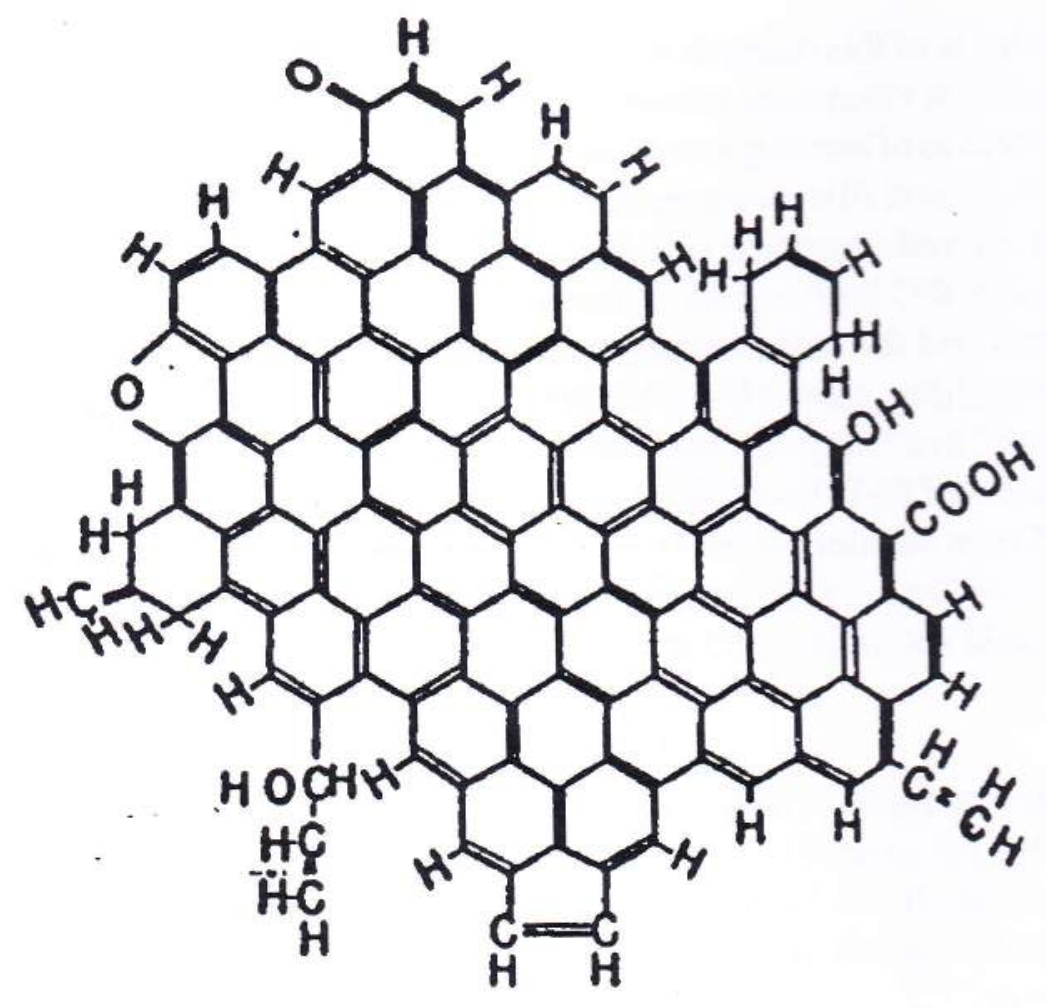

Gambar 1 : Gugus fungsional pada permukaan carbon black 
Produksi filler penguat barang karet di dunia mengandalkan pada proses kimia cracking hidrokarbon dari bahan minyak bumi menjadi elemen karbon yang disebut carbon black. Dengan makin berkurangnya cadangan minyak bumi dunia, bahan baku carbon black akan makin langka sehingga perlu dicari bahan lain sebagai substitusinya. Kayu keruing (Depterocarpus sp.) merupakan salah satu kayu hutan yang banyak diproduksi dan tumbuh di pulau Sumatera, Jawa dan Kalimantan. Berdasarkan Atlas Kayu Indonesia (1981), komposisi kayu keruing terdiri dari selulosa $51,4 \%$, lignin $19,2 \%$, pentosan $16,8 \%$, abu $0,9 \%$, silika $0,6 \%$.

Pemecahan rantai karbon dalam minyak bumi dengan bantuan panas disebut sebagai proses thermal cracking hidrokarbon. Karena pengaruh energi panas pada suhu tinggi, ikatan antar karbon dalam senyawa hidrokarbon minyak bumi mengalami pemutusan rantai, menjadi ikatan baru dengan panjang rantai karbon yang lebih kecil bahkan sampai menjadi agregat karbon (Shreve and Brink, 1977). Selulosa dalam limbah industri kayu mempunyai struktur rantai yang mirip dengan hidrokarbon dalam minyak bumi. Rantai yang panjang dalam selulosa ini dimungkinkan dapat dipecah menjadi agregat karbon dan senyawa-senyawa kimia dengan berat molekul rendah, dengan pemberian energi panas pada suhu yang tinggi (thermal cracking selulosa). Proses tersebut diharapkan dapat mengubah limbah kayu keruing menjadi filler penguat barang karet.

Untuk mengetahui sifat filler kayu keruing dan kesesuaiannya sebagai filler barang karet, maka perlu diteliti aplikasinya dalam pembuatan vulkanisat karet dan salah satunya adalah sol sepatu.

\section{BAHAN DAN METODA PENELITIAN}

\section{Bahan Penelitian}

Bahan penelitian terdiri atas karet RSS I, carbon black N330 (ukuran partikel $31 \mathrm{~nm}$, absorpsi iodin $80,7 \mathrm{~g} / \mathrm{kg}$, bound rubber $36,47 \%$ ), arang aktif kayu keruing (lolos 400 mesh $\approx 250 \mu$, absorpsi iodin $148,1 \mathrm{~g} / \mathrm{kg}$, bound rubber $20,48 \%$ ), zink oksida, asam stearat, benzothiazyl disulfide (MBTS), belerang, potongan kayu keruing $(2 \times 2 \times 2 \mathrm{~cm})$, garam $\mathrm{NaCl}$ $4 \%$.

\section{Peralatan Penelitian}

Alat penelitian terdiri atas reaktor thermal cracking, gergaji listrik, ayakan Tyler 400 mesh, mesin two roll mill (Toyo Seiki, kap. 1000 g), hidrolik pres (Carver laboratory press, 20 ton) rheometer (Conical disk rheometer model 100 Toyo Seiki), alat uji tensile strength (Lloyd instrument), alat uji kekerasan (Toyo Seiki durometer A), alat uji kikis Grasselli, alat uji De-Mattia flex cracking dan alat uji permanent set.

\section{Cara Penelitian}

\section{Rancangan percobaan}

Dalam penelitian ini faktor yang dipelajari meliputi pengaruh filler kayu keruing dan carbon black secara sendiri maupun kombinasi untuk pembuatan vulkanisat sol sepatu dengan variasi filler seperti tertera pada Tabel 1.

Perlakuan dan analisis dibuat tiga ulangan sedangkan parameter yang diamati meliputi : tegangan putus, perpanjangan putus, ketahanan sobek, bobotjenis, kekerasan, ketahanan kikis Grasselli, perpanjangan tetap dan ketahanan retak lentur. 
Tabel 1. Variasi filler dalam rancangan penelitian

\begin{tabular}{|c|c|c|c|c|c|c|c|}
\hline No. & Karet & $\begin{array}{c}\text { Filler Kayu } \\
\text { Keruing } \\
\text { (FK) }\end{array}$ & $\begin{array}{c}\text { Carbon } \\
\text { Black } \\
\text { (CB) }\end{array}$ & No. & Karet & $\begin{array}{c}\text { Filler Kayu } \\
\text { Keruing } \\
\text { (FK) }\end{array}$ & $\begin{array}{c}\text { Carbon } \\
\text { Black } \\
\text { (CB) }\end{array}$ \\
\hline 1. & 100 & 20 & 0 & 13. & 100 & 0 & 60 \\
2. & 100 & 30 & 0 & 14. & 100 & 0 & 70 \\
3. & 100 & 40 & 0 & 15. & 100 & 0 & 80 \\
4. & 100 & 50 & 0 & 16. & 100 & 0 & 100 \\
5. & 100 & 60 & 0 & 17. & 100 & 20 & 60 \\
6. & 100 & 70 & 0 & 18. & 100 & 40 & 40 \\
7. & 100 & 80 & 0 & 19. & 100 & 60 & 20 \\
8. & 100 & 100 & 0 & 20. & 100 & 20 & 50 \\
9. & 100 & 0 & 20 & 21. & 100 & 40 & 30 \\
10. & 100 & 0 & 30 & 22. & 100 & 60 & 10 \\
11. & 100 & 0 & 40 & 23. & 100 & 20 & 40 \\
12. & 100 & 0 & 50 & 24. & 100 & 40 & 20 \\
\hline
\end{tabular}

\section{Pembuatan filler}

Pembuatan filler kayu keruing dilakukan melalui tahapan berikut :

a. Proses karbonisasi atau pirolisis, dilakukan dalam reaktor pirolisa pada suhu $450^{\circ} \mathrm{C}$ selama 1 jam. Pirolisis merupakan proses peruraian kayu dengan udara terbatas atau tanpa udara dan hasilnya adalah arang. Arang merupakan residu pembakaran yang sebagian besar komponennya berupa karbon.

b. Proses aktivasi, dilakukan dengan menggunakan aktivator $\mathrm{NaCl} 4 \%$ selama 1 jam, filler dicuci dengan air dilanjutkan dengan pirolisis pada suhu $500^{\circ} \mathrm{C}$ selama $1 \mathrm{jam}$. Proses ini dimaksudkan untuk memperluas permukaan filler dengan cara menghilangkan ter yang masih melekat pada permukaan dan pori-pori arang. Filler hasil diuji terhadap luas permukaan (absorpsi iodin) dan nilai karet terikat (bound rubber).

\section{Pembuatan kompon dan vulkanisat}

1. Standar formula kompon sesuai dengan ASTM D3192: Standard method for Carbon black in natural rubber - recipe and evaluation procedures sebagai berikut : karet alam $100,0 \mathrm{phr}$, asam stearat 3,0 phr, zink oksida 5,0 phr, benzothyazil disulfide $0,60 \mathrm{phr}$, belerang $2,50 \mathrm{phr}$. Dalam penelitian ini filler divariasi.

2. Proses komponding (pencampuran karet dengan bahan-bahan kimia) dilakukan dengan alat two roll mill sesuai metode A (open mill) ASTM D-3192.

3. Vulkanisasi dilakukan pada suhu $150^{\circ} \mathrm{C}$, tekanan $150 \mathrm{~kg} / \mathrm{cm}^{2}$ dengan waktu sesuai yang ditunjukkan oleh rheometer.

\section{Pengujian}

Vulkanisat karet pada berbagai variasi filler diuji dalam aplikasinya untuk sol sesuai cara uji sol karet dalam SNI.12-0172-1987 : Sepatu Kanvas untuk Umum. 


\section{HASIL PENELITIAN DAN PEMBAHASAN}

\section{Hasil penelitian seperti tertera pada Tabel 2.}

Tabel 2 : Hasil uji sifat fisik vulkanisat karet dengan berbagai variasi filler

\begin{tabular}{|c|c|c|c|c|c|c|c|c|c|}
\hline No. & $\begin{array}{l}\text { Perb. } \\
\text { FK:CB }\end{array}$ & $\begin{array}{l}\text { Tegang- } \\
\text { an putus } \\
\mathrm{N} / \mathrm{mm}^{2}\end{array}$ & $\begin{array}{c}\text { Perpan- } \\
\text { jangan } \\
\text { Putus \% }\end{array}$ & $\begin{array}{c}\text { Ketahan- } \\
\text { an Sobek } \\
\mathrm{N} / \mathrm{mm}^{2}\end{array}$ & $\begin{array}{l}\text { Ketahan- } \\
\text { an Kikis } \\
\mathrm{mm}^{3} / \mathrm{kgm}\end{array}$ & $\begin{array}{l}\text { Bobot } \\
\text { Jenis } \\
\mathrm{g} / \mathrm{cm}^{3} \\
\end{array}$ & $\begin{array}{c}\text { Kekeras- } \\
\text { an } \\
\text { Shore A }\end{array}$ & $\begin{array}{l}\text { Perpan- } \\
\text { jangan } \\
\text { Tetap \% }\end{array}$ & $\begin{array}{c}\text { Ketahan- } \\
\text { an Retak } \\
\text { Lentur }\end{array}$ \\
\hline 1. & $100: 0$ & 3,57 & 284 & 3,04 & 5,67 & 1,06 & 69,6 & 2,45 & Retak \\
\hline 2. & $0: 100$ & 7,24 & 126 & 7,18 & 0,45 & 1,24 & 82,7 & 3,27 & Patah \\
\hline 3. & $0: 80$ & 10,61 & 365 & 10,34 & 0,68 & 1,19 & 75,7 & 3,47 & Retak \\
\hline 4. & $20: 60$ & 8,14 & 421 & 6,63 & 1,49 & 1,16 & 71,8 & 2,98 & Retak \\
\hline 5. & $40: 40$ & 8,72 & 375 & 6,58 & 1,884 & 1,15 & 72,4 & 2,43 & Retak \\
\hline 6. & $60: 20$ & 5,23 & 437 & 4,99 & 2,69 & 1,11 & 67,2 & 1,82 & Retak \\
\hline 7. & $80: 0$ & 4,20 & 456 & 4,39 & 4,96 & 1,10 & 68,5 & 1,73 & Retak \\
\hline 8. & $0: 70$ & 13,37 & 572 & 13,44 & 0,29 & 1,17 & 72,7 & 3,55 & Retak \\
\hline 9. & $20: 50$ & 9,76 & 575 & 8,17 & 1,07 & 1,15 & 70,0 & 3,15 & Retak \\
\hline 10. & $40: 30$ & 9,02 & 544 & 5,16 & 2,10 & 1,13 & 67,5 & 2,35 & Retak \\
\hline 11. & $60: 10$ & 5,01 & 510 & 4,69 & 3,14 & 1,12 & 64,0 & 2,37 & Retak \\
\hline 12. & $70: 0$ & 5,68 & 583 & 4,48 & 4,01 & 1,09 & 65,6 & 1,92 & Retak \\
\hline 13. & $0: 60$ & 12,96 & 769 & 13,26 & 0,52 & 1,15 & 67,9 & 2,97 & Retak \\
\hline 14. & $20: 40$ & 10,02 & 723 & 8,20 & 1,14 & 1,13 & 67,7 & 1,83 & Retak \\
\hline 15. & $40: 20$ & 9,22 & 669 & 5,02 & 2,63 & 1,09 & 64,7 & 1,82 & Retak \\
\hline 16. & $60: 0$ & 5,24 & 675 & 4,03 & 4,52 & 1,07 & 62,7 & 1,36 & Patah \\
\hline 17. & $50: 0$ & 7,09 & 776 & 4,34 & 2,74 & 1,08 & 59,5 & 0,70 & Retak \\
\hline 18. & $40: 0$ & 9,26 & 1075 & 4,94 & 3,03 & 1,04 & 57,7 & 1,20 & Retak \\
\hline 19. & $30: 0$ & 9,47 & 1252 & 4,03 & 2,76 & 1,03 & 52,9 & 0,72 & Retak \\
\hline 20. & $20: 0$ & 12,86 & 1682 & 7,99 & 2,79 & 1,01 & 47,5 & 1,02 & Retak \\
\hline 21. & $0: 50$ & 15.20 & 970 & 13.06 & 0.61 & 1.13 & 62,0 & 2.60 & Retak \\
\hline 22. & $0: 40$ & 17,60 & 1252 & 14,19 & 0,69 & 1,11 & 58,7 & 1,95 & Retak \\
\hline 23. & $0: 30$ & 18.00 & 1410 & 12.0 & 1.10 & 1.07 & 53,0 & 1.68 & Retak \\
\hline 24. & $0: 20$ & 18,67 & 1575 & 10,01 & 1,51 & 1,04 & 47,2 & 1,43 & Retak \\
\hline
\end{tabular}

\section{Pembahasan}

a. Sifat filler terhadap tegangan putus

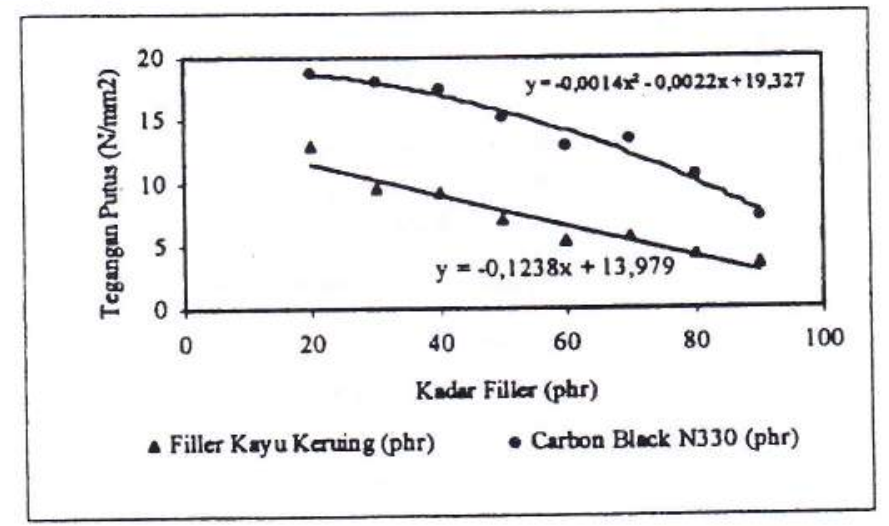

Gambar 2 : Tegangan putus vulkanisat karet 
Pada Gambar 2 terlihat bahwa sifat tegangan putus dipengaruhi oleh jumlah filler yang ditambahkan. Makin besar kadar filler kayu keruing tegangan putus turun, sedangkan carbon black menunjukkan nilai maksimum pada kadar 20-40 phr dan turun pada kadar yang lebih besar. Ini sesuai dengan penelitian Byers (1987) bahwa penambahan carbon black seri N300 sebesar 20-40 phr diperoleh tegangan putus maksimum dan turun pada penambahan yang lebih besar.

Ditinjau dari tegangan putus maka filler kayu keruing mempunyai nilai lebih rendah dan berbeda nyata $(0,05)$ dibanding carbon black N330. Hal ini disebabkan karena carbon black dengan ukuran partikel kecil mempunyai luas permukaan lebih besar yang memungkinkan terjadi interaksi baik secara fisika maupun kimia lebih baik. Secara fisika terjadi adsorpsi molekul karet melalui tenaga van der Waal's sedangkan secara kimia terbentuk ikatan antara karet dengan gugus fungsional pada permukaan filler. Karet alam merupakan polimer yang terdiri dari unit-unit isopren $\left(\mathrm{C}_{5} \mathrm{H}_{8}\right)$ dan tiap unit isopren terdapat satu ikatan ganda. Ikatan ganda tersebut serta gugus $\mathrm{C}_{1} \alpha$ metilen adalah gugus reaktif untuk terbentuknya ikatan kimia. Ikatan-ikatan yang terbentuk mengakibatkan vulkanisat kaku dan kuat sehingga tidak mudah putus dan memerlukan beban yang besar apabila ditarik. Hubungan tegangan putus dengan peningkatan kadar filler kayu keruing adalah $y=-0,1238 x+13,979 ; y=$ tegangan putus $\left(\mathrm{N} / \mathrm{mm}^{2}\right), \mathrm{x}=$ kadar filler. Selain itu rendahnya nilai tegangan putus filler kayu keruing dapat disebabkan oleh hilangnya gugus-gugus fungsional pada permukaan karbon pada proses aktivasi dan pirolisis. Hal tersebut terlihat dari nilai karet terikat (bound rubber) yang lebih rendah yakni 20,48 \% dibanding carbon black sebesar 36,47\%. Nilai karet terikat menunjukkan besarnya molekul karet yang dapat berikatan dengan filler secara kimia. Meskipun filler kayu keruing memberikan nilai tegangan putus lebih rendah dibanding carbon black, namun penambahannya sampai dengan 70 phr memenuhi syarat SNI 120172-1989 sebesar minimal 5,0 N/mm² . Kombinasi penggunaan filler kayu keruing dengan carbon black menunjukkan bahwa makin banyak proporsi carbon black nilai tegangan putus makin tinggi. Penambahan filler kayu keruing sebesar 25 - $85 \mathrm{phr}$ dalam formulasi kombinasi masih memenuhi syarat SNI.

b. Sifat filler terhadap perpanjangan putus

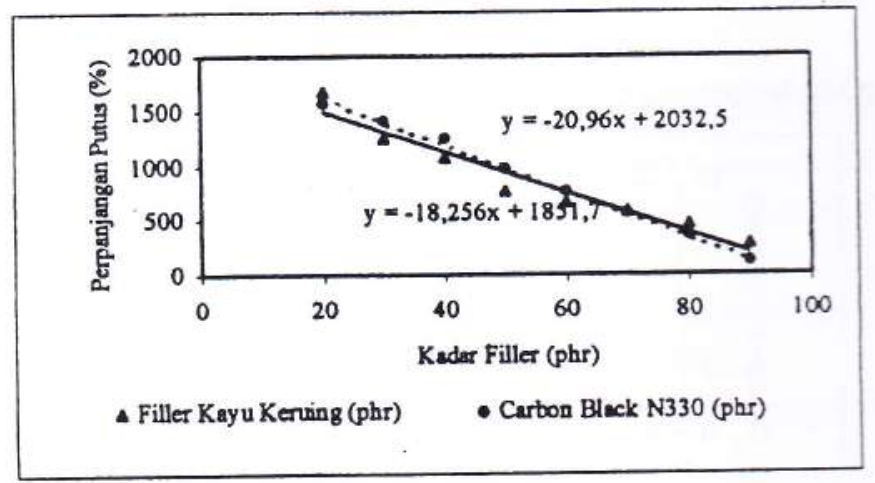

Gambar 3 : Perpanjangan putus vulkanisat karet

Berdasarkan Gambar 3 telihat bahwa makin banyak filler yang ditambahkan perpanjangan putus turun secara nyata $(\mathrm{P} \leq 0,05)$. Meskipun semua vulkanisat karet menunjukkan penurunan nilai perpanjangan putus, tetapi masih memenuhi syarat SNI. 12- 
0172-1987 sebesar minimum 100\%. Hubungan antara nilai perpanjangan putus dengan peningkatan penambahan filler kayu keruing menunjukkan garis linier dengan rumus $\mathrm{y}=$ $18.256 \mathrm{x}+1851,7 ; \mathrm{y}=$ perpanjangan putus $(\%), \mathrm{x}=$ kadar filler kayu keruing. Penurunan perpanjangan putus disebabkan karena terbentuknya ikatan-ikatan antara molekul karet dengan gugus fungsional pada permukaan filler. Banyaknya ikatan yang terbentuk akan mengurangi keleluasaan gerak rantai polimer, menyebabkan viskositas kompon meningkat, kompon menjadi kaku, keras, dan elastisitasnya turun. Filler kayu keruing menunjukkan penurunan perpanjangan putus lebih kecil dibanding carbon black, karena ikatan-ikatan yang terbentuk baik secara fisika maupun kimia lebih rendah dibanding carbon black sehingga vulkanisat lebih elastis. Selain itu makin besar jumlah filler yang ditambahkan, dapat mengakibatkan terjadinya aglomerasi agregat karena tidak semua filler dapat mengadsorpsi maupun berikatan dengan molekul karet. Keadaan tersebut disebabkan karena jenuhnya molekul karet yang dapat berikatan dengan filler sehingga apabila vulkanisat ditarik mudah putus atau perpanjangan putusnya rendah.

c. Sifat filler terhadap ketahanan sobek

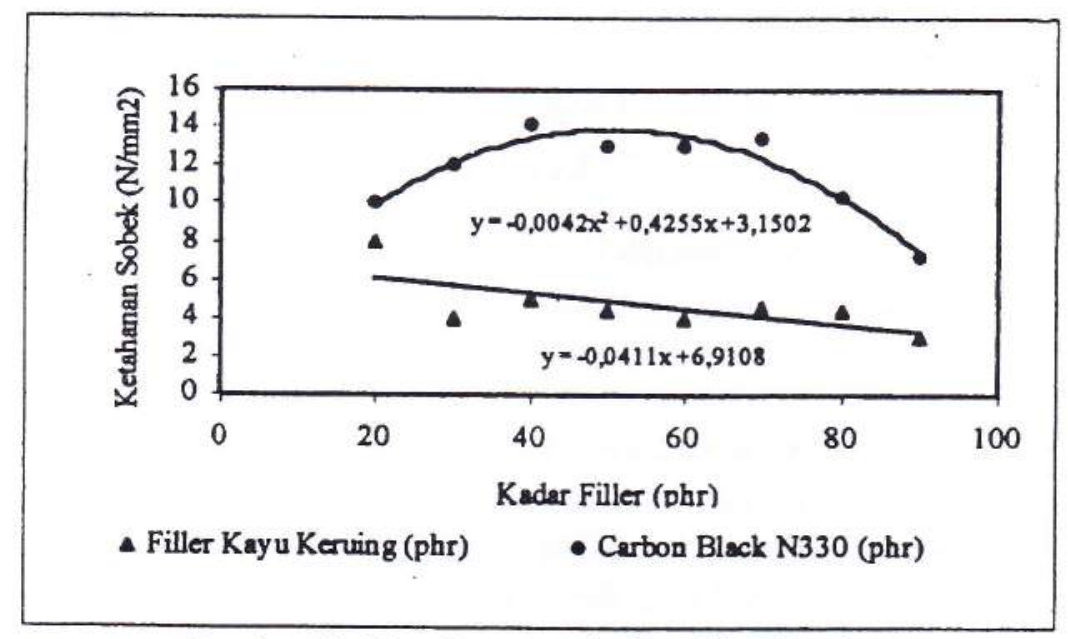

Gambar 4 : Ketahanan sobek vulkanisat karet

Berdasarkan Gambar 4 terlihat bahwa makin besar kadar filler kayu keruing ketahanan sobek vulkanisat turun. Meskipun demikian penggunaan filler kayu keruing dalam semua formulasi yang diteliti masih dapat memenuhi syarat SNI. 12-0172-1987 sebesar minimum $2,5 \mathrm{~N} / \mathrm{mm}^{2}$. Hubungan ketahanan sobek dengan peningkatan kadar filler kayu keruing adalah $y=-0,0411 x+6,9108 ; y=$ ketahanan sobek $\left(N / \mathrm{mm}^{2}\right), x=$ kadar filler kayu keruing.

Dibanding dengan carbon black N 330 ketahanan sobek filler kayu keruing lebih rendah, hal ini disebabkan karena dispersi dan distribusi carbon black N 330 lebih baik dan merata sebab ukuran partikelnya jauh lebih kecil. Akibatnya interaksi antara karet dengan filler akan lebih baik sehingga ketahanan sobeknya tinggi. Menurut Dannenberg (1980) ukuran partikel yang besar, yakni $>325$ mesh akan menurunkan ketahanan sobek sampai $50 \%$. Selain itu filler kayu keruing mempunyai nilai karet terikat (bound rubber) yang lebih kecil yaitu $20,48 \%$ dibanding carbon black $\mathrm{N} 330$ sebesar $36,47 \%$. Nilai karet terikat yang besar menunjukkan bahwa filler mempunyai tenaga adsorpsi terhadap karet yang besar pula, sehingga kekuatan vulkanisat lebih tinggi. 
Penambahan carbon black pada kadar $40 \mathrm{phr}$, ketahanan sobek meningkat secara nyata $(\mathrm{P} \leq 0,05)$ dan menunjukkan puncak pada grafik, namun penambahan yang lebih besar ketahanan sobek turun. Hal tersebut sesuai dengan penelitian Byers (1987) yang mendapatkan bahwa penambahan carbon black seri N300 sebesar 35-50 phr memberikan ketahanan sobek maksimal, tetapi penambahan yang lebih besar menyebabkan ketahanan sobek vulkanisat karet turun.

Pada kombinasi filler kayu keruing dengan carbon black N330 menunjukkan bahwa makin besar proporsi carbon black nilai ketahanan sobek makin tinggi. Kadar filler kayu keruing antara 25-85 phr dalam formulasi kombinasi memenuhi syarat SNI.

d. Sifat filler terhadap kekerasan

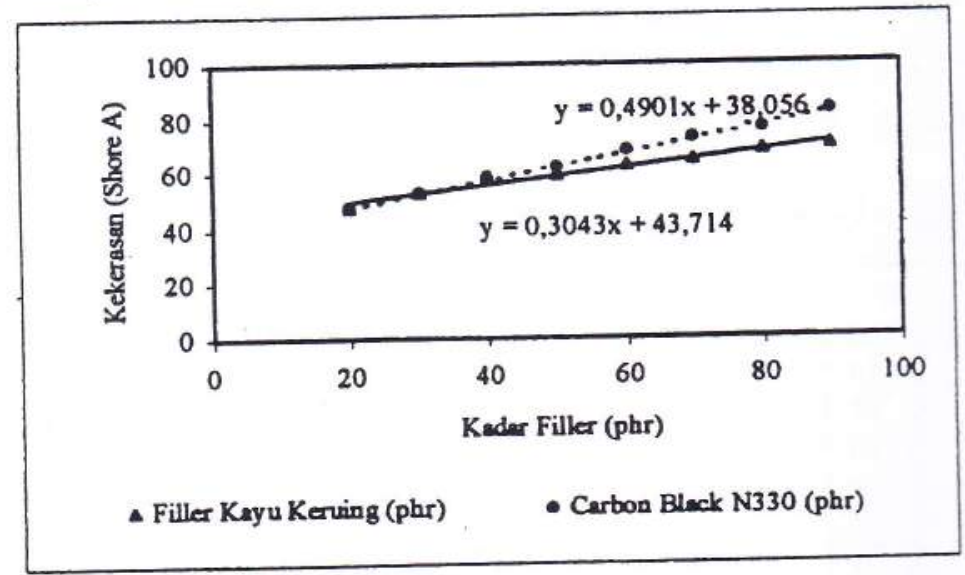

Gambar 5 : Kekerasan vulkanisat karet

Gambar 5 menunjukkan bahwa makin besar kadar filler, kekerasan makin meningkat. Nilai kekerasan sangat dipengaruhi oleh jenis dan banyaknya filler yang ditambahkan dalam kompon karet, selain juga oleh banyaknya ikatan silang yang terbentuk. Makin banyak ikatan terbentuk, vulkanisat makin kuat, kaku, dan keras.

Filler mempunyai sifat lebih padat dan keras dibanding bahan karet, sehingga makin besar kadar filler dalam kompon karet akan meningkatkan kekerasan vulkanisat. Kekerasan vulkanisat dengan filler kayu keruing lebih rendah dibanding vulkanisat dengan filler carbon black karena ukuran partikel filler kayu keruing relatif besar (400 mesh) sehingga kurang terdispersi dengan baik dan merata dalam kompon karet, akibatnya ikatan yang terbentuk tidak sebesar pada carbon black.

Hubungan peningkatan kadar filler kayu keruing dengan kekerasan adalah $y=0,3043 \mathrm{x}$ $+43,714 ; \mathrm{y}=$ kekerasan vulkanisat (shore A), $\mathrm{x}=$ kadar filler kayu keruing

Persyaratan kekerasan sol berdasar SNI.12-0172-1987, adalah sebesar 55-75 shore A dan untuk mencapai persyaratan tersebut diperlukan kadar filler kayu keruing maupun carbon black minimal $40 \mathrm{phr}$. Penambahan filler kayu keruing sampai kadar $100 \mathrm{phr}$ diperoleh nilai kekerasan 69,6 shore A dan memenuhi syarat SNI. Dengan demikian ditinjau dari kekerasan, filler kayu keruing menguntungkan karena dapat ditambahkan dalam jumlah lebih besar daripada carbon black. Kombinasi penggunaan filler kayu keruing sebesar 25-85 phr dalam formulasi kombinasi masih memenuhi SNI. 
e. Sifat filler terhadap ketahanan kikis Grasselli

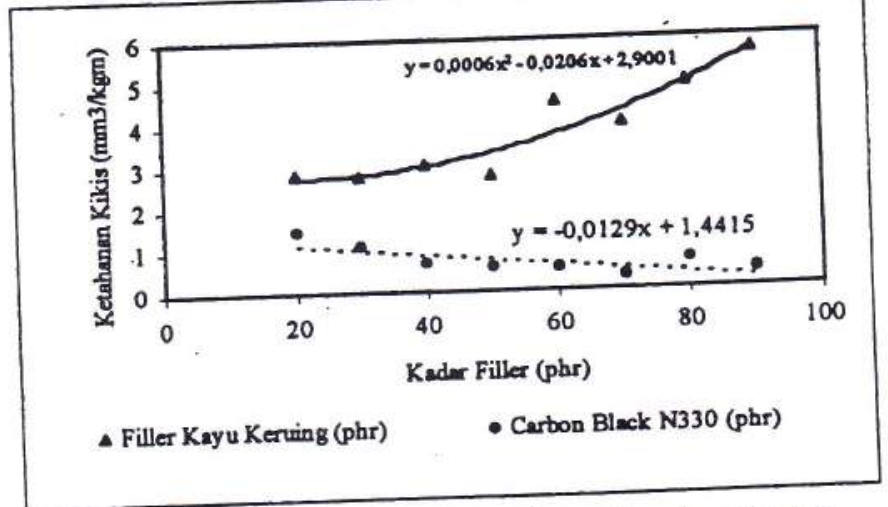

Gambar 6: Ketahanan kikis vulkanisat karet

Ketahanan kikis Grasselli diukur dari besarnya volume karet terkikis per satuan usaha $\left(\mathrm{mm}^{3} / \mathrm{kgm}\right)$. Makin kecil volume karet terkikis per satuan usaha makin baik karena menunjukkan ketahanan kikis yang tinggi.

Pada gambar 6 ternyata makin besar kadar filler kayu keruing, ketahanan kikis vulkanisat karet makin kecil. Hubungan antara kenaikan kadar filler kayu keruing dengan ketahanan kikis adalah $y=0,0006 x^{2}-0,0206 x+2,9001$. Penggunaan filler kayu keruing memberikan nilai ketahanan kikis antara 2,76-5,67 $\mathrm{mm}^{3} / \mathrm{kgm}$, sehingga belum memenuhi persyaratan sol karet dalam SNI.12-0172-1987 sebesar maksimum 2,50 $\mathrm{mm}^{3} / \mathrm{kgm}$. Rendahnya nilai ketahanan kikis vulkanisat dengan filler kayu keruing dapat disebabkan karena partikelnya relatif besar sehingga dispersinya dalam kompon karet tidak sebaik dan merata dibanding carbon black. Oleh karena itu interaksinya dengan molekul karet rendah. Disamping itu meskipun luas permukaan filler kayu keruing lebih besar daripada carbon black dengan nilai absorpsi iodin $148,1 \mathrm{~g} / \mathrm{kg}$, namun kemungkinan banyak mempunyai permukaan bagian dalam (pori) yang hanya sedikit mengandung gugus fungsional. Hilangnya gugus fungsional filler kayu keruing dapat terjadi pada proses aktivasi dan pirolisis, akibatnya ikatan kimia yang terbentuk relatif kecil. Dibanding filler kayu keruing,vulkanisat karet dengan carbon black N 330 menunjukkan ketahanan kikis tinggi dan berbeda nyata $(\mathrm{p} \leq 0,05)$. Makin besar kadar carbon black makin tinggi ketahanan kikisnya. Hal ini disebabkan karena makin besar kadar carbon black, vulkanisat makin keras dan makin sulit terkikis. Selain itu carbon black N 330 adalah filler penguat yang tergolong mempunyai ketahanan kikis tinggi (high abrasion furnace black). Kombinasi carbon black N330 dengan filler kayu keruing meningkatkan ketahanan kikis vulkanisat, makin besar proporsi carbon black ketahanan kikis makin tinggi. Penambahan filler kayu keruing sebesar 25-57 phr dalam formulasi kombinasi memenuhi syarat SNI.

f. Sifat filler terhadap bobot jenis

Berdasarkan hasil uji bobot jenis (Gambar 7) terlihat bahwa makin besar jumlah filler yang ditambahkan dalam kompon karet, bobot jenis makin meningkat secara nyata ( $\mathrm{p} \leq$ 0,05). Semua formulasi yang diteliti dapat memenuhi syarat SNI.12-0172-1987 sebesar maksimum $1,5 \mathrm{~g} / \mathrm{cm}^{3}$. Dibandingkan penggunaan carbon black N 330, maka penggunaan filler kayu keruing ditinjau dari bobot jenisnya lebih baik karena lebih kecil. Hal ini disebabkan karena filler kayu keruing lebih porous dan mempunyai luas permukaan bagian dalam (in- 


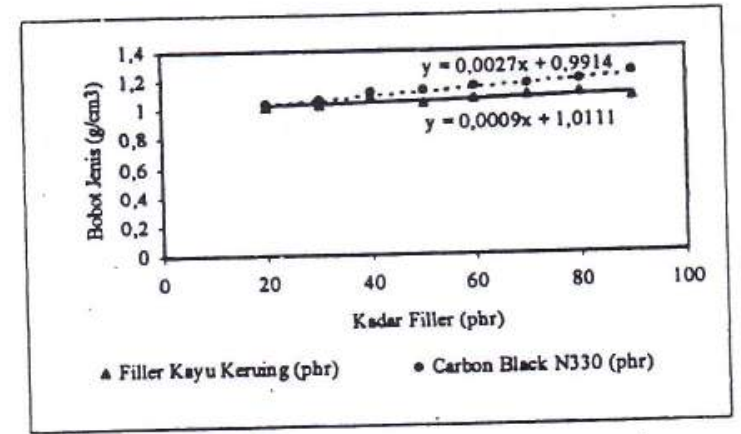

Gambar 7 : Bobot jenis vulkanisat karet

ternal surface) relatif lebih besar yakni dengan nilai adsorpsi iodin sebesar $148,1 \mathrm{~g} / \mathrm{kg}$ dibandingkan carbon black N 330 sebesar $80,79 \mathrm{~g} / \mathrm{kg}$. Dengan demikian vulkanisat dengan filler kayu keruing bersifat ringan dan cocok untuk sol sepatu. Hubungan antara kadar filler kayu keruing dengan bobot jenis adalah $y=0,0009 x+1,0111$. Kombinasi penggunaan filler kayu keruing dengan carbon black N 330 menunjukkan bahwa makin besar proporsi filler kayu keruing, bobot jenis vulkanisat makin rendah.

g. Sifat filler terhadap perpanjangan tetap

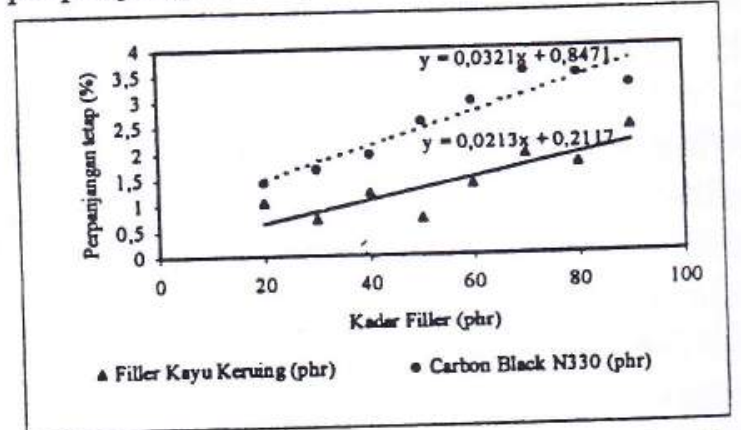

Gambar 8 : Perpanjangan tetap vulkanisat karet

Perpanjangan tetap (permanent set) menunjukkan kemampuan vulkanisat karet untuk kembali kebentuk semula apabila dilakukan penarikan pada panjang dan waktu tertentu. Gambar 8 menunjukkan bahwa perpanjangan tetap vulkanisat karet dipengaruhi oleh kadar filler.Makin besar kadar filler, perpanjangan tetap turun, namun masih dapat memenuhi syarat SNI.12-0172-1987 sebesar maksimum 10\%. Makin besar kadar filler dan makin banyak ikatan yang terbentuk antara karet dengan filler, vulkanisat karet makin keras dan kaku. Akibatnya apabila ditarik pada perpanjangan 50\% selama 24 jam akan terjadi deformasi permanen. Filler kayu keruing menunjukkan penurunan nilai perpanjangan tetap lebih kecil dibanding carbon black N 330 . Hubungan kenaikan kadar filler dan perpanjangan tetap adalah $\mathrm{y}=0,0233 \mathrm{x}+0,2112 ; \mathrm{y}=$ perpanjangan tetap $(\%), \mathrm{x}=$ kadar filler kayu keruing.

Hal tersebut disebabkan karena ikatan-ikatan yang terbentuk antara karet dengan filler kayu keruing lebih kecil dengan nilai karet terikat (bound rubber) 20,48\% dibanding carbon black $36,47 \%$. Oleh karena itu bersifat lebih elastis dibanding carbon black, hingga apabila ditarik mudah kembali kebentuk semula. Kombinasi filler kayu keruing dengan carbon black menunjukkan bahwa makin besar proporsi filler kayu keruing, perpanjangan tetap makin kecil. 
h. Sifat filler terhadap ketahanan retak lentur

Berdasarkan hasil uji terhadap ketahanan retak lentur ternyata semua vulkanisat yang diuji, baik dengan filler kayu keruing, carbon black maupun kombinasinya retak pada pembengkukan $150 \mathrm{kcs}$ atau 150.000 kali sehingga tidak memenuhi syarat SNI.

Ketahanan retak lentur selain dipengaruhi oleh jumlah dan jenis filler, juga formula dan komposisinya. Dari hasil uji terhadap 24 vulkanisat yang diteliti baik dengan filler kayu keruing maupun carbon black dan kombinasinya mulai kadar 20 sampai dengan $100 \mathrm{phr}$ ternyata menunjukkan keretakan.

Hal ini menunjukkan bahwa formula standar (ASTM D 3192) yang terdiri dari karet alam $100 \mathrm{phr}$, akselerator MBTS 0,6 phr, aktivator ZnO $5 \mathrm{phr}$, asam stearat $3 \mathrm{phr}$, dan belerang 2,5 phr serta filler (divariasi) belum sesuai untuk formula sol. Formulasi sol memerlukan bahan kimia karet lainnya seperti antioksidan/antidegradan dan pelunak (process oil). Antioksidan/antidegradan diperlukan untuk mencegah oksidasi karet dan pemutusan rantai polimer sedangkan pelunak (proses oil) diperlukan untuk meningkatkan ketahanan retak lentur, elastisitas dan kemudahan filler terdispersi dalam kompon karet.

\section{KESIMPULAN}

1. Sifat filler kayu keruing ditinjau dari tegangan putus, ketahanan sobek, ketahanan kikis, perpanjangan tetap, dan ketahanan retak lentur masih belum dapat menyamai carbon black N330.

2. Filler kayu keruing mempunyai bobot jenis lebih rendah daripada carbon black $\mathrm{N} 330$, sehingga sesuai dalam aplikasinya untuk sol sepatu.

3. Filler kayu keruing mempunyai potensi untuk mensubtitusi carbon black dalam pembuatan barang karet.

4. Pemanfaatan limbah kayu keruing sebagai filler barang karet akan mengurangi filler impor sekaligus mengatasi dampak lingkungan.

\section{DAFTAR PUSTAKA}

Anonim, 1989. Atlas Kayu Indonesia. Lembaga Penelitian Hasil Hutan Indonesia. Bogor. Byers, J.T., 1987. Fillers Part I: Carbon Black, dalam Maurice Morton, ed., Rubber Technology. Van Nostrand Reinhold. New York.

Hofmann, W., 1989. Rubber Technology Hand Book Hauser Publisher. Munich Vienna. New York.

Jankowska, H., A. Swiatkowski and J. Choma, 1991. Active Carbon. Ellis Horwood Limited, England.

Maurya, G.P., 1981. Rubber Technology and Manufacture. Small Business Publication. New Delhi.

Morton, M., 1987. Rubber Technology. Third edition. Van Nostrand Reinhold. New York.

Patel, A.C. and W.A. Brown, 1985. Carbon Black Structure and Viscoelastic Properties of Rubber Compounds. A presented The Rubber Divisions American Chemical Society, 127th meeting. Los Angeles. California. April 23-26.

Shreve, R.N. and J.A. Bring, 1977. Chemical Proses Industries. Mc GrawHill International Book Company. London.

Stearns R.S and Johnson B.L, 1951. Rubber Chemistry and Technology. Volume XXIV No. 1 Division of Rubber Chemistry. American Chemical Society.

Majalah Barang Kulit, Karet dan Plastik, Vol. XV, No. 2, Tahun 1999 